\author{
Jurnal IImiah AL-Jauhari (JIAJ) \\ Volume 3 No 1, Juni 2018 \\ ISSN: $2541-3430$ \\ E-ISSN: 2541-3449 \\ Halaman 79-96
}

\title{
Penerapan Nilai-Nilai Pendidikan Antikorupsi di Madrasah Tsanawiyah Al-Yusra Gorontalo
}

\author{
Oleh: \\ Nurindah Bau
}

\begin{abstract}
Abstrak
Upaya yang dilakukan oleh pemerintah untuk menumbuhkan nilai-nilai pendidikan antikorupsi disekolah, salah satunya memasukkan kedalam kurikulum sekolah dengan cara mengintegrasikan kedalam mata pelajaran, bertujuan untuk menanamkan nilai dan sikap hidup anti korupsi kepada warga sekolah. Jenis penelitian ini adalah kualitatif. Dalam pengumpulan data metode yang digunakan adalah wawancara, observasi, dan dokumentasi yang didukung dengan data teoritis melalui telaah pustaka (library research).

Penelitian menunjukkan bahwa, Pendidikan Antikorupsi terintegrasi studi pada mata pelajaran Akidah akhlak dan Pendidikan Kewarganegaraan sudah diterapkan di Madrasah Tsanawiyah Al-Yusra Gorontalo. Penerapan nilai-nilai pendidikan antikorupsi, terintegrasi studi pada mata pelajaran Akidah akhlak dan Pendidikan Kewarganegaraan, diterapkan melalui perencanaan, pelaksanaan dan evaluasi, dilakukan dengan penanaman nilai antikorupsi, meliputi: jujur, disiplin, kerja sama, sederhana, peduli, mandiri, ketulusan, integritas, kewarganegaraan, yang relevan dengan materi bahasan, yang dapat diamati dari sikap siswa melalui Lingkungan sosial peserta didik, dan nilai-nilai islami peserta didik.
\end{abstract}

Kata Kunci: Penerapan, Nilai-Nilai, Pendidikan Antikorupsi,

\section{Pendahuluan}

Latar belakang pendidikan antikorupsi ditinjau dari: 1) praktek korupsi di Indonesia telah terjadi sejak masa kerajaan diwilayah nusantara bahkan telah tersistematisasi mulai pada masa VOC dan pemerintahan Hindia Belanda, 2) Secara faktual persoalan korupsi di Indonesia, dikatakan telah sampai pada kulminasi yang akut, tidak hanya mewabah dikultur dan struktur birokrasi pemerintahan, melainkan juga telah menjadi fenomena multidimensional dan telah menggorogoti sendi-sendi kehidupan sosial dan kultur, 3) Pergeseran pola hidup masyarakat yang tadinya menjunjung tinggi nilai-nilai materialistis dan 
konsumerisme, 4) Korupsi di Indonesia sudah tergolong kejahatan luar biasa (common ordinary crime). ${ }^{1}$ Upaya menjadikan musuh bersama (common emery) belum menjadi bagian dari gerakan moral bangsa, hingga sampai saat ini virus korupsi semakin menjangkiti hampir setiap lapisan elemen masyarakat dari tingkat atas (pemerintah) sampai pada tingkat bawah (rakyat).

Upaya pencegahan budaya korupsi dimasyarakat terlebih dahulu dapat dilakukan dengan mencegah berkembangnya mental korupsi pada anak bangsa Indonesia melalui pendidikan. Pendidikan adalah proses yang sangat penting didalam kehidupan manusia. Karena pendidikan sebagai kewajiban yang harus ditempuh dan pada akhirnya menjadi rutinitas. Pendidikan melahirkan seorang yang berilmu, yang dapat menjadi khalifah Allah dibumi ini.

Pendidikan Kewarganegaraan (PKn) merupakan salah satu mata pelajaran sebagai muatan wajib kurikulum pendidikan dasar dan menengah (Pasal 37 Ayat 1 Undang-Undang Sistem Pendidikan Nasional). Selanjutnya dalam lampiran Peraturan Menteri Pendidikan Nasional) Nomor 22 Tahun 2006 tentang standar isi ditegaskan bahwa PKn termasuk cakupan mata pelajaran dan kepribadian, yang dimaksudkan untuk peningkatan kesadaran dan wawasan peserta didik tentang status, hak, dan kewajibannya didalam kehidupan masyarakat, berbangsa dan bernegara, serta peningkatan kualitas dirinya sebagai manusia.

Dalam kaitannya dengan Pendidikan Agama Islam, adalah bagian integral dari pendidikan nasional sebagai suatu keseluruhan. Dalam UU No. 20 tahun 2003 tentang sistim Pendidikan Nasional pasal 37 ayat 1 menjelaskan bahwa, Kurikulum pendidikan dasar dan menengah wajib memuat antara lain pendidikan agama. $^{2}$

\section{Landasan Yuridis.}

Landasan yuridis merupakan aturan atau norma-norma yang berlaku dalam bentuk Undang-Undang positif Indonesia yang mengatur tentang kehidupan masyarakat sesuai dengan ketentuan yang berlaku dalam suatu daerah guna untuk dapat menjalankan tugas dan fungsinya sesuai dengan tata aturan Negara Indonesia.

1) Undang - Undang Dasar tahun 1945

2) Undang-Undang Nomor 7 Tahun 2006 sebagai pengesahan atas konvensi perserikatan bangsa-bangsa antikorupsi.

3) Keputusan Direktur Jenderal Pendidikan Islam nomor : 1696 tahun 2013, tentang panduan penyelenggaraan pendidikan antikorupsi di Madrasah.

Landasan agama juga memiliki tujuan dan fungsi yang sama dengan landasan yuridis yaitu sama-sama ingin menciptakan individu dan lingkungan masyarakat Indonesia yang baik dan bersih.

Dalam ajaran Islam, secara gamblang mengharamkan korupsi, seperti tersirat dalam beberapa ayat Al-Qur'an, diantaranya;

\footnotetext{
${ }^{1}$ Amirulloh Syarbini, Muhammad Arbain, Pendidikan Antikorupsi, (Bandung: Alfabeta, 2014), hlm. 9.

${ }^{2}$ Ibid, Amirulloh Syarbini, Muhammad Arbain, Pendidikan Antikorupsi, hlm. 10.
} 


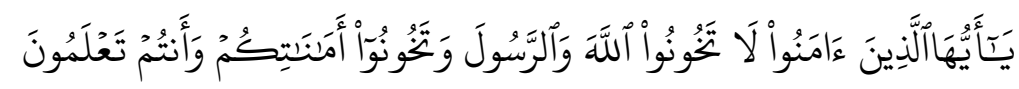

Terjemahnya:

Hai orang-orang yang beriman, janganlah kamu mengkhianati Allah dan Rasul (Muhammad) dan (juga) janganlah kamu mengkhianati amanat-amanat yang dipercayakan kepadamu, sedang kamu mengetahui. QS. Al-Anfal:27. ${ }^{3}$

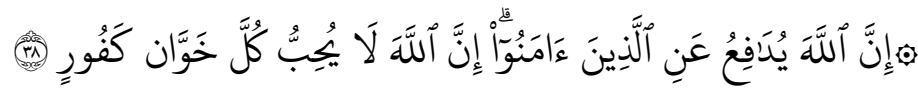

Terjemahnya:

Sesungguhnya Allah membela orang-orang yang telah beriman. Sesungguhnya Allah tidak menyukai tiap-tiap orang yang berkhianat lagi mengingkari nikmat. QS. Al-Hajj: $38 .^{4}$

Berdasarkan dari firman Allah SWT dan hadis Rasulullah SAW disatu sisi, dan menyimak pengertian korupsi disisi yang lain, dengan demikian korupsi merupakan perbuatan penghianatan terhadap amanah dan tanggung jawab yang diberikan rakyat. Korupsi juga merupakan tindakan memakan harta sebagian yang lain dengan cara batil, karena korupsi menghabiskan harta milik Negara yang seharusnya digunakan untuk kepentingan rakyat. ${ }^{5}$

Pendidikan antikorupsi bukan sekedar media bagi transfer pengalihan pengetahuan (kognitif) namun juga menekankan pada upaya pembentukan karakter (afektif) dan kesadaran moral dalam melakukan perlawanan (psikomotorik) terhadap perilaku penyimpangan korupsi. Karakter merupakan hal yang sangat penting dan mendasar. Karakter adalah mustika hidup yang membedakan manusia dangan binatang. Orang-orang yang berkarakter kuat dan baik secara induvial ialah mereka yang memiliki akhlak, moral, dan budi pekerti yang baik. Mengingat begitu urgennya karakter, maka institusi pendidikan memiliki tanggung jawab untuk menanamkannya melalui program antikorupsi yang disisipkan pada mata pelajaran disekolah.

Dalam materi pendidikan di sekolah dapat berperan dalam memberantas korupsi secara tidak langsung melalui pengaitan materi pembelajaran secara kontekstual dengan pesan yang ingin disampaikan berkenaan dengan korupsi.

\section{Integrasi Materi Pendidikan Antikorupsi}

Berkaitan dengan integrasi materi pendidikan antikorupsi nantinya bisa saja diselipkan dalam mata pelajaran Pendidikan Kewarganegaraan (PKn) serta Akidah akhlak, pokok bahasan mencakup kejujuran, kedisiplinan, kesederhanaan, Tanggung jawab, kerja keras, mandiri, adil, berani, integritas, peduli dan Kewarganegaraan.

Dengan demikian korupsi dalam konteks pendidikan adalah tindakan untuk mengendalikan atau mengurangi korupsi yang juga merupakan seluruh upaya

\footnotetext{
${ }^{3}$ Mohammad Taufiq, Qur'an in World Ver 1.0.0.

${ }^{5}$ Ibid, Amirulloh Syarbini, Muhammad Arbain, Pendidikan Antikorupsi, hlm. 11.
} 
mendorong generasi-generasi mendatang mengembangkan sikap menolak secara tegas setiap bentuk tindak korupsi. ${ }^{6}$

Nilai moral adalah suatu bagian dari nilai, yaitu nilai yang menangani kelakuan baik atau buruk dari manusia. Moral selalu berhubungan dengan nilai, tetapi tidak semua nilai adalah nilai moral. Moral berhubungan dengan kelakuan atau tindakan manusia. Nilai moral inilah yang lebih terkait dengan tingkah laku kehidupan kita sehari-hari. ${ }^{7}$

Pendapat para ahli tersebut, penulis berkesimpulan bahwa yang dimaksud dengan nilai adalah,"sesuatu yang bermanfaat bagi umat manusia untuk menentukan perbuatan itu baik atau buruk". Oleh karena itu, nilai bersifat menyeluruh,bulat dan terpadu sehingga kebulatan itu mengandung aspek normatif dan operatif. Dilihat dari segi normatif nilai sebagai pertimbangan baik dan buruk,serta benar dan salah. dilihat dari segi operatif nilai mengandung lima kategori perilaku manusia, yaitu wajib, sunah, mubah, makruh dan haram. ${ }^{8}$

Pendapat Ki Hadjar Dewantoro dijelaskan bahwa memaknai pendidikan sebagai tuntutan dalam hidup tumbuhnya anak-anak, maksud dari pernyataan tersebut adalah menuntun segala kekuatan kodrat yang ada pada anak-anak agar mereka dapat mencapai keselamatan dan kebahagiaan yang setinggi-tingginya baik bagi dirinya maupun anggota masyarakat. ${ }^{9}$ Mendidik adalah memberi pertolongan secara sadar dan sengaja kepada seorang anak (yang belum dewasa) dalam pertumbuhan menuju kearah kedewasaan dalam artian dapat berdiri sendiri dan bertanggung jawab susila atas segala tindakannya menurut pilihannya sendiri.

Implementasi pendidikan antikorupsi melalui pembelajaran terintegrasi pada mata pelajaran akidah akhlak dan Pendidikan Kewarganegaraan di kelas IX di MTs AL-Yusra Gorontalo, implementasi adalah merupakan hal mendasar, implementasi ditemukan dalam kamus bahasa Indonesia yang artinya adalah suatu tindakan atau pelaksanaan dari sebuah rencana yang telah disusun secara matang dan terpeinci. ${ }^{10}$ Implementasi biasanya dilakukan setelah perencanaan sudah dianggap matang. Perencanaan yang dibuat sedemikian rupa oleh guru dalam hal mengintegrasikan nilai-nilai pendidikan antikorupsi dalam mata pelajaran akidah akhlak dan PKn.

\section{Hakekat Nilai-nilai Pendidikan Antikorupsi.}

Hakikatnya pendidikan adalah upaya memanusiakan manusia dan membudayakan manusia, sehingga mampu mencipta,berkarya, berbudi baik diri bagi kehidupan.

Coruptio berasal dari kata corrumpere,suatu kata latin yang lebih tua. Dari bahasa latin itulah turun ke bahasa Eropa, seperti Inggris yaitu, corruption,

\footnotetext{
hlm. 23 .

${ }^{6} I b i d$, David Wijaya.dkk, Pendidikan Antikorupsi untuk Sekolah dan Perguruan Tinggi,

${ }^{7}$ Ibid, Muhamad Nurdin, Nilai-nilai Pendidikan Antikorupsi hlm. 37.

${ }^{8}$ Rohmat Mulyana, Mengartikulasikan Pendidikan Nilai, (Bandung: Alfabeta, 2011), hlm 10.

${ }^{9}$ Haedar Nashir, Pendidikan Karakter Berbasis Agama dan Budaya, ( Yokyakarta: Multi Presindo, 2013), hlm. 16.

${ }^{10}$ Ibid, Nurkholif Hazin, Kamus Lengkap Bahasa Indonesia Super Baru, hlm. 233.
} 
corrupt ; Prancis yaitu corruption; dan Belanda yaitu corruptie, korruptie. Dari bahasa Belanda inilah kata itu turun ke bahasa Indonesia yaitu korupsi.Kata "korup" berarti kebusukan, keburukan, kebejatan, ketidakjujuran, dapat disogok/suap, tidak bermoral, penyimpangan dari kesucian, dan kata-kata atau ucapan yang memfitnah. ${ }^{11}$ Dalam Islam korupsi disebut risywah yang berarti penyuapan/uang selain disebut sebagai tindakan penyuapan, korupsi juga disebut ghulul (penggelapan), ghasab (mengambil paksa hak/harta orang lain), sariqah (pencurian), khiyanah (pelanggaran kepercayaan), dan hirabah (perampokan). ${ }^{12}$ Dilihat dari sudut terminologi, istilah korupsi berasal dari kata "corruption" dalam bahasa latin yang berarti kerusakan atau kebobrokan,dan dipakai pula menunjuk suatu keadaan atau perbuatan yang busuk. ${ }^{13}$

Korupsi yang muncul di Indonesia dipicu oleh beberapa hal, seperti: ${ }^{14}$

a) Masih lemahnya karakter bangsa

b) Pemahaman terhadap ajaran ajaran agama tidak diaplikasikan dalam kehidupan sehari-hari.

c) Belum terbangunnya sistem pembangunan,pemerintahan,dan pembangunan berkelanjutan.

d) Belum berkembangnya nasionalisme kemanusiaan serta demokrasi politik dan ekonomi.

e) Belum terejawantahnya nilai-nilai utama dan belum berkembangnya sistem yang memungkinkan masyarakat untuk mengadopsi dan memaknai nilai-nilai kontemporer secara bijaksana.

f) Kegamangan dalam menghadapi masa depan serta rentannya system pembangunan,pemerintahan,dan kenegaraan dalam menghadapi perubahan.

Kondisi yang mendukung terjadinya korupsi adalah sebagai berikut: ${ }^{15}$

a) Konsentrasi kekuasaan di pengambil keputusan yang tidak bertanggung jawab langsung kepada rakyat,seperti yang sering terlihat direzim-rezim yang bukan demokrat.

b) Kurangnya transparansi dipengambilan keputusan pemerintah.

c) Kampanye-kampanye politik yang mahal,dengan pengeluaran lebih besar dari pendanaan politik yang normal.

d) Proyek yang melibatkan uang rakyat dalam jumlah besar.

e) Lingkungan tertutup yang mementingkan diri sendiri dan jaringan teman lama.

f) Lemahnya ketertiban hukum.

g) Lemahnya profesi hukum

h) Kurangnya kebebasan berpendapat atau kebebasan media masa.

i) Gaji pemerintah yang sangat kecil.

j) Rakyat yang cuek tidak tertarik atau mudah dibohongi yang gagal memberikan perhatian kepemilihan umum.

\footnotetext{
${ }^{11}$ Ibid,Amirulloh Syarbini, Muhammad Arbain, Pendidikan Antikorupsi, hlm 5.

${ }^{12}$ Ibid, Amirulloh Syarbini, Muhammad Arbain, Pendidikan Antikorupsi, hlm. 6.

${ }^{13}$ Elwi Danil,Konsep, Tindak Pidana, dan pemberantasannya,(Jakarta:PT Raja Grafindo Persada, 2014), hlm. 3

${ }^{14}$ Siti Mutiah, Korupsi Subur,Negara Hancur, (Bandung: Angkasa, 2011), hlm. 8.

${ }^{15}$ Ibid, hlm. 9.
} 
k) Ketidakadaannya kontrol yang cukup untuk mencegah penyuapan atau sumbangan kampanye.

a. pendidikan antikorupsi adalah usaha sadar untuk memberi pemahaman dan pencegahan terjadinya perbuatan korupsi yang dilakukan dari pendidikan formal disekolah, pendidikan informal pada lingkungan keluarga, dan pendidikan non formal dimasyarakat. Pendidikan antikorupsi tidak berhenti pada pengenalan nilai-nilai antikorupsi saja, akan tetapi, berlanjut pada pemahaman nilai, penghayatan nilai dan pengamalan nilai antikorupsi menjadi kebiasaan hidup sehari-hari. $^{16}$

\section{Tujuan Pendidikan Antikorupsi.}

Tujuan yang hendak dicapai dalam Pendidikan Antikorupsi disekolah adalah untuk:

a. Menanamkan nilai dan sikap hidup antikorupsi kepada warga sekolah.

b. Menumbuhkan kebiasaan perilaku antikorupsi kepada warga sekolah.

c. Mengembangkan kreativitas warga sekolah dalam memasyarakatkan dan membudayakan perilaku antikorupsi. ${ }^{17}$

Semangat antikorupsi yang patut menjadi kajian adalah penanaman pola pikir, sikap, dan perilaku antikorupsi melalui sekolah, karena sekolah adalah proses pembudayaan. Sektor pendidikan formal di Indonesia dapat berperan dalam memenuhi kebutuhan pencegahan korupsi. Langkah preventif (pencegahan) tersebut secara tidak langsung bisa melalui dua pendekatan di lingkungan sekolah maupun dilingkungan masyarakat. Pertama : menjadikanpeserta didik sebagai target, dan kedua: menggunakan pemberdayaan peserta didik untuk menekan lingkungan agar tidak permissive to corruption.

\section{Paradigma Nilai-Nilai Pendidikan Antikorupsi.}

Paradigma adalah suatu kerangka konseptual, termasuk nilai, teknik dan metode, yang disepakati dan digunakan oleh suatu komunitas dalam memahami atau mempersepsi segala sesuatu. Dengan demikian, fungsi utama paradigma adalah sebagai acuan dalam mengarahkan tindakan, baik tindakan sehari-hari maupun tindakan ilmiah.

\section{Kejujuran}

Saat ini masih menjadi fenomena dikalangan siswa yaitu, budaya ketidakjujuran. Fakta menunjukkan bahwa, budaya ketidakjujuran kian menggejala di kalangan siswa. Bahkan akar dari masalah korupsi, kolusi dan nepotisme di Indonesia adalah murni dari faktor ketidakjujuran pada waktu menjadi siswa. Contoh budaya ketidakjujuran siswa, misalnya: mencontek, maka teman yang di contek tentunya telah terampas keadilan dan kemampuannya. Ketika siswa yang di contek belajar siang malam, tetapi penyontek yang suka hura-hura dengan gampangnya mencuri hasil kerja keras temannya.

\section{Disiplin}

Disiplin belajar pada siswa yang terbentuk melalui proses dari serangkaian perilaku yang menunjukkan nilai-nilai ketaatan, dan keteraturan berdasarkan acuan nilai moral individu untuk

\footnotetext{
${ }^{16}$ Ibid, Amirulloh Syarbini, Muhammad Arbain, Pendidikan Antikorupsi, hlm. 7.

${ }^{17}$ Ibid, Amirulloh Syarbini, Muhammad Arbain, Pendidikan Antikorupsi, hlm. 12.
} 
memperoleh perubahan tingkah laku yang mencakup perubahan berfikir, sikap dan tindakan yang sesuai dengan standar sosial. Ini berarti, bahwa disiplin belajar yang ada pada siswa terbentuk berdasarkan nilai moral.

\section{Kepedulian}

Sikap kepedulian sosial yang dimiliki oleh setiap siswa, maka sangatlah mungkin jika timbul sebuah tanda tanya mengenai cara untuk menumbuhkan sikap kepedulian dalam diri seorang siswa. Sehingga sikap kepedulian hanya cukup dapat dibentuk melalui jalan pembelajaran yang telah termuat didalam pembelajaran, maka sangatlah mungkin jika terdapat korelasi yang signifikan antara prestasi belajar yang telah dicapai siswa dengan kepeduliannya.

\section{Kerjasama}

Kerjasama yang baik antara guru dan siswa menjadi tolak ukur sejauh mana siswa dijadikan bagian dari proses belajar mengajar yang baik. Artinya siswa tidak lagi dianggap sebagai obyek dari proses pembelajaran, tapi ia merupakan subyek dari proses pembelajaran yang dapat mengantarkan kedua belah pihak (baik guru dan siswa) sama-sama mendapatkan kemajuan dalam menuntut ilmu, kemajuan dalam proses pembelajaran, dan kemajuan dalam penerapan ilmu pengetahuan.

\section{Sederhana}

Untuk hidup sederhana, sebagai seorang siswa dapat membentengi dan membenahi paradigma untuk tidak bersifat boros. Serta memotivasi kepada siswa yang lain untuk tidak berlebihan dalam segala hal. Misalnya: dalam berpakaian agar tidak menampilkan pakaian yang mahal serta tidak memakai perhiasan di sekolah, sebagaimana tercantum dalam peraturan sekolah. Berdasarkan uraian diatas, diharapkan dapat tercipta suasana sekolah yang penuh dengan keharmonisan dan keakrapan antara siswa.

\section{Kemandirian}

Hiduplah secara mandiri, karena disitu terdapat kebahagiaan. Dalam program pembelajaran menuntut kemandirian siswa dalam hal menentukan cara belajar. Sebaliknya program pembelajaran yang banyak memberi peluang dialog, siswa akan memiliki kemandirian dalam menentukan tujuan dan isi pelajaran.

\section{Ikhlas}

Ikhlas dalam islam ibaratnya adalah sebuah kunci untuk memasuki sebuah rumah. Tanpa kunci maka kita tidak akan bisa memasuki rumah tersebut. Dipaksa masuk maka kita tak ubahnya seperti maling yang ingin mencuri dan mengancurkan rumah tersebut. Jika islam maka ikhlaslah dalam berislam dan menjalani. Ikhlas juga merupakan sebuah persyaratan mutlak untuk diterimanya sebuah ibadah diterima oleh Allah SWT. Baik itu ibadah ritual maupun ibadah sosial.

\section{Integritas}

Integritas merupakan kualitas bersikap jujur dan selalu memiliki prinsipprinsip moral yang tinggi. Integritas adalah tanpa topeng, bertindak sesuai dengan yang diucapkan, konsisten antara ucapan dan perbuatan, serta sikap dan tindakan. Sedangkan, moral adalah ajaran tentang baik buruk yang diterima umum 
mengenai perbuatan, sikap, kewajiban, dan sebagainya. Integritas moral dapat dibangun kembali untuk mengembalikan moral anak bangsa Indonesia yang luhur.

\section{Kewarganegaraan}

Perwujudan semangat kewarganegaraan dan kemanusiaan dalam perilaku interaktif guru-siswa dan siswa-siswa, dan penciptaan iklim demokratis dalam rangka pengambilan keputusan. Untuk itu maka proses pembelajaran pendidikan demokrasi perlu dikembangkan dengan menerapkan pendekatan belajar yang bersifat memberdayakan siswa.

\section{Penerapan Nilai-Nilai Pendidikan Antikorupsi Dalam Pembelajaran.}

Penerapan nilai-nilai pendidikan antikorupsi bisa dilakukan kesemua mata pelajaran. Khususnya pada MTs Al- Yusra Gorontalo kelas IX, pada materi iman kepada Allah, dalam sikap kejujuran dalam mata pelajaran Akidah akhlak, yaitu guru menerangkan bahwa hari akhir pasti akan datang, sesuai dengan ajaran Islam, inilah yang dimaksud dengan kejujuran. Guru menerangkan tentang hakikat kejujuran, pentingnya kejujuran, dan dampak kejujuran, dalam kehidupan sehari-hari. Seorang guru Akidah akhlak tidak hanya menerangkan bahwa hari akhir pasti datang.

Berikut ini implimentasi nilai-nilai pendidikan antikorupsi dalam pembelajaran:

\section{Mata Pelajaran Akidah Akhlah}

\section{a) Kejujuran}

Kejujuran merupakan bagian dari sifat positif manusia. Kejujuran adalah bagian dari harga diri yang harus dijaga karena bernilai tinggi.

Firman Allah SWT (QS. Al-Ahzab : 70-71):

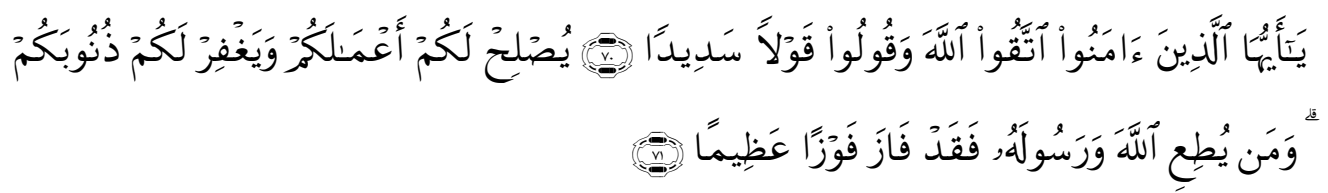

Terjemahnya:

70. Hai orang-orang yang beriman, bertakwalah kamu kepada Allah dan Katakanlah Perkataan yang benar,

71. niscaya Allah memperbaiki bagimu amalan-amalanmu dan mengampuni bagimu dosa-dosamu. dan barangsiapa mentaati Allah dan Rasul-Nya, Maka Sesungguhnya ia telah mendapat kemenangan yang besar. ${ }^{18}$

\section{b) Disiplin}

Disiplin merupakan perasaan taat dan patuh terhadap nilai-nilai yang dipercaya termasuk melakukan pekerjaan tertentu yang menjadi tanggung jawabnya. Perkataan disiplin mempunyai arti latihan dan ketaatan kepada aturan. Dengan melaksanakan disiplin, berarti semua pihak dapat menjamin kelangsungan hidup dan kelancaran kegiatan belajar, bekerja, dan berusaha.

Firman Allah SWT (QS. Al-Jumuah: 9-10):

\footnotetext{
${ }^{18}$ Mohammad Taufiq, Qur'an in World Ver 1.0.0
} 


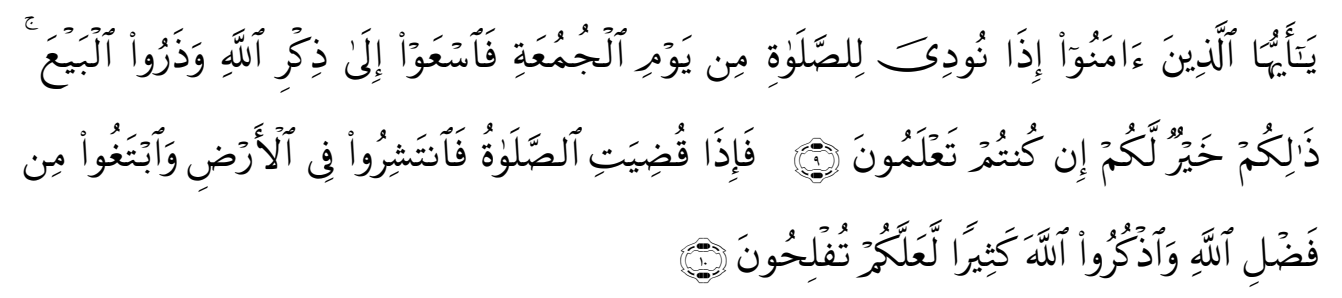

Terjemahnya:

9. Hai orang-orang beriman, apabila diseru untuk menunaikan shalat Jum'at, maka bersegeralah kamu kepada mengingat Allah dan tinggalkanlah jual beli, yang demikian itu lebih baik bagimu jika kamu mengetahui.

10. Apabila telah ditunaikan shalat, maka bertebaranlah kamu di muka bumi dan carilah karunia Allah dan ingatlah Allah banyak-banyak supaya kamu beruntung. ${ }^{19}$

\section{c) Kepedulian}

Kepedulian terhadap sesama atau biasa disebut dengan istilah kepedulian sosial adalah sikap memerhatikan atau menghiraukan urusan orang lain (sesama anggota masyarakat).

Firman Allah SWT (QS. Al-Hujurat: 10):

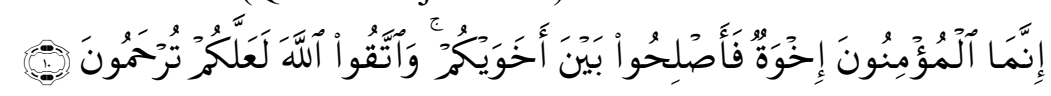

Terjemahnya:

Orang-orang beriman itu Sesungguhnya bersaudara. sebab itu damaikanlah (perbaikilah hubungan) antara kedua saudaramu itu dan takutlah terhadap Allah, supaya kamu mendapat rahmat. ${ }^{20}$

\section{d) Kerjasama}

Kerjasama antar siswa dalam kegiatan belajar dapat memberikan berbagai pengalaman. Mereka lebih banyak mendapatkan kesempatan berbicara, inisiatif, menentukan pilihan dan secaraumum mengembangkan kebiasaan yang baik. Siswa yang sama-sama bekerja dalam kelompok akan menimbulkan persahabatan yang akrab, yang terbentuk dikalangan siswa, ternyata sangat berpengaruh pada tingkah laku atau kegiatan masing-masing secara individual.

Firman Allah SWT (QS. Ali Imran: 103):

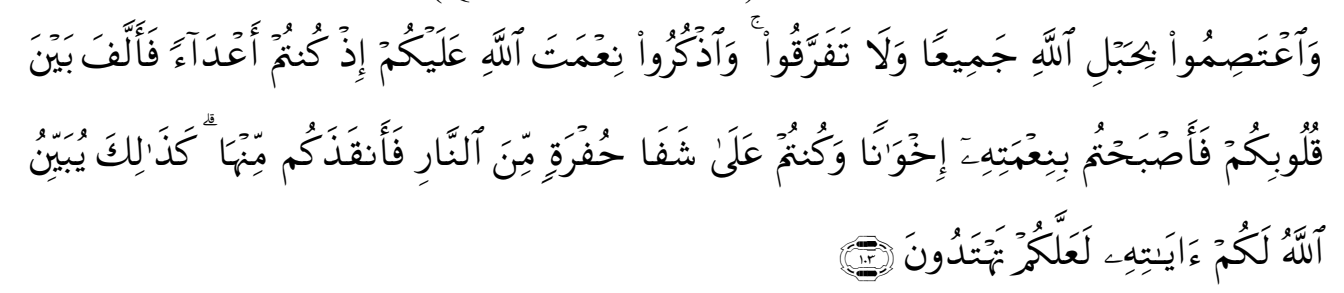

\footnotetext{
${ }^{19}$ Mohammad Taufiq, Qur'an in World Ver 1.0.0

${ }^{20}$ Mohammad Taufiq, Qur'an in World Ver 1.0.0
} 
Terjemahnya:

Dan berpeganglah kamu semuanya kepada tali (agama) Allah, dan janganlah kamu bercerai berai, dan ingatlah akan nikmat Allah kepadamu ketika kamu dahulu (masa Jahiliyah) bermusuh-musuhan, Maka Allah mempersatukan hatimu, lalu menjadilah kamu karena nikmat Allah, orang-orang yang bersaudara; dan kamu telah berada di tepi jurang neraka, lalu Allah menyelamatkan kamu dari padanya. Demikianlah Allah menerangkan ayatayat-Nya kepadamu, agar kamu mendapat petunjuk. ${ }^{21}$

\section{e) Sederhana}

Sepertinya batasan hidup sederhana itu bersifat relatif. Tergantung dari perspektif orang yang memandang dan telah menjalani pola hidup sederhana itu. Dari sudut mana orang tersebut memandang sikap hidup sederhana. Namun secara umum hidup sederhana adalah pola hidup keluarga yang tidak berlebihan menurut norma-norma tertentu yang berlaku dalam masyarakat.

Firman Allah SWT (QS. Al-Furqan : 67):

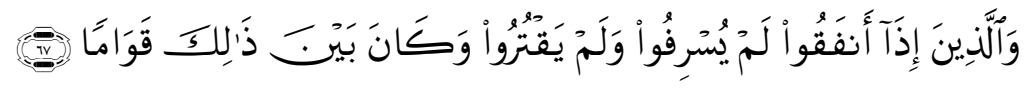

Terjemahnya:

Dan orang-orang yang apabila membelanjakan (harta), mereka tidak berlebihan, dan tidak (pula) kikir, dan adalah (pembelanjaan itu) di tengahtengah antara yang demikian. ${ }^{22}$

\section{Mata Pelajaran Pendidikan Kewarganegaraan a) Kemandirian}

Kemandirian membutuhkan tenaga dan biaya yang lebih besar. Tapi efek jangka panjang dari kemandirian bisa melunasi tenaga dan biaya tadi berkali lipat. Kemandirian adalah sikap (perilaku) dan mental yang memungkinkan seseorang untuk bertindak bebas, benar, dan bermanfaat, berusaha melakukan segala sesuatu dengan jujur dan benar atas dorongan dirinya sendiri dan kemampuan mengatur diri sendiri, sesuai dengan hak dan kewajibannya, sehingga dapat menyelesaikan masalah-masalah yang dihadapinya; serta bertanggung jawab terhadap segala keputusan yang telah diambilnya melalui berbagai pertimbangan sebelumnya.

Firman Allah SWT (QS. Al-Mulk: 15);

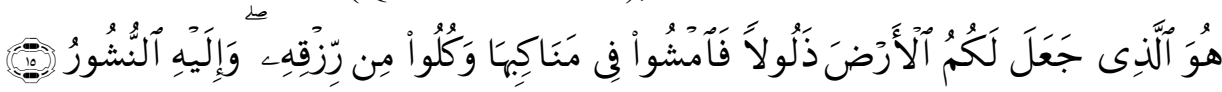

Terjemahnya:

Dialah yang menjadikan bumi itu mudah bagi kamu, Maka berjalanlah di segala penjurunya dan makanlah sebahagian dari rezki-Nya. dan hanya kepada-Nya-lah kamu (kembali setelah) dibangkitkan. ${ }^{23}$

\footnotetext{
${ }^{21}$ Mohammad Taufiq, Qur'an in World Ver 1.0.0

${ }^{22}$ Mohammad Taufiq, Qur'an in World Ver 1.0.0
} 


\section{b) Ikhlas}

Ikhlas itu adalah sebuah kesulitan yang nyata. Keikhlasan itu adalah sebuah kunci untuk sebuah kebaikan dan kebenaran dalam kehidupan. Sebenarnya, tidak ada yang sulit dalam kehidupan manusia. Karena Allah telah menciptkan manusia sebagai makhluk sempurna sebagai manusia.

Firman Allah SWT (QS. Al-Bayinnah: 15);

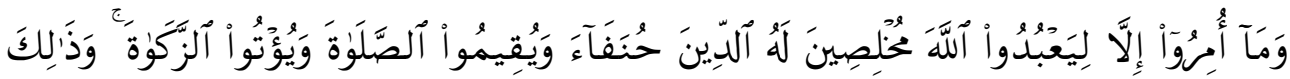

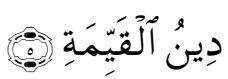

Terjemahnya:

Padahal mereka tidak disuruh kecuali supaya menyembah Allah dengan memurnikan ketaatan kepada-Nya dalam (menjalankan) agama yang lurus, dan supaya mereka mendirikan shalat dan menunaikan zakat; dan yang demikian Itulah agama yang lurus. ${ }^{24}$

\section{c) Integritas}

integritas adalah tindakan yang sifatnya berkelanjutan sesuai dengan apa yang sudah menjadi prinsip (sejalan antara yang dikatakan dan di lakukan). Integritas sangatlah berpengaruh dalam kehidupan kita bahkan juga kepada masyarakat dan dunia, karena berbicara mengenai integritas kita belajar mengenai kejujuran, ketulusan, kebenaran, tanggung jawab dan keikhlasan.

Firman Allah SWT (QS. Asyu'araa: 137):

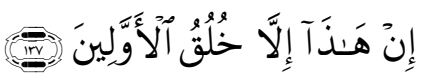

Terjemahnya:

(Agama kami) ini tidak lain hanyalah adat kebiasaan orang dahulu ${ }^{25}$

\section{d) Kewarganegaraan}

Salah satu cara yang dapat dilakukan dalam mengimplementasikan nilai nilai luhur yang terkandung dalam Pancasila adalah dengan menerapkan Pendidikan Pancasila atau yang saat ini sering disebut dengan Pendidikan Kewarganegaraan (PKn). Pendidikan Pancasila adalah salah satu materi pelajaran moral yang ada di setiap bangku pendidikan.

Firman Allah SWT (QS, Yusuf: 106):

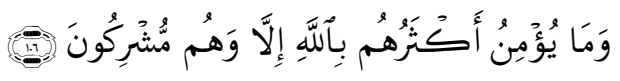

Terjemahnya:

\footnotetext{
${ }^{23}$ Mohammad Taufiq, Qur'an in World Ver 1.0.0

${ }^{24}$ Mohammad Taufiq, Qur'an in World Ver 1.0.

${ }^{25}$ Mohammad Taufiq, Qur'an in World Ver 1.0.
} 
Dan sebahagian besar dari mereka tidak beriman kepada Allah, melainkan dalam Keadaan mempersekutukan Allah (dengan sembahan-sembahan lain). ${ }^{26}$

\section{E. Identifikasi Nilai-Nilai Pendidikan Antikorupsi}

Identifikasi nilai-nilai antikorupsi amatlah perlu guna untuk mengetahui nilai-nilai apa saja yang harus dikembangkan dalam diri peserta didik supaya dapat menumbuhkembangkan sikap dan perilaku yang antikorupsi. Sehingga nilai-nilai ini dapat melekat dalam jiwa dan setiap tindakan yang ia lakukan dan tetap pada koridor yang baik dan benar.

Berdasarkan hasil identifikasi, ada beberapa nilai-nilai yang akan dibahas oleh penulis dalam pendidikan antikorupsi di kelas IX MTs Al-Yusra Gorontalo. Nilainilai antikorupsi tersebut adalah sebagai berikut: jujur, disiplin, peduli, kerja sama, sederhana, mandiri, ketulusan, kewarganegaraan, integritas.

\section{F. Bentuk Nilai-Nilai Pendidikan Antikorupsi}

\section{Mata Pelajaran Akidah Akhlak}

a) Jujur

Kata jujur dapat didefinisikan sebagai lurus hati, tidak berbohong dan tidak curang. Jujur adalah salah sifat yang sangat penting dalam kehidupan peserta didik. Nilai kejujuran di sekolah dapat diwujudkan dalam bentuk tidak melakukan kecurangan. Misalnya: tidak mencontek, tidak memalsukan nilai. kelompok diskusi tersebut.

\section{b) Disiplin}

Disiplin adalah ketaatan atau kepatuhan kepada peraturan. Hidup disiplin bagi peserta didik adalah dapat mengatur dan mengelola waktu yang ada untuk dipergunakan dengan sebaik-baiknya untuk menyelesaikan tugas baik dalam lingkup akademik sekolah maupun kehidupan sosial. Misalnya: tidak terlambat kesekolah, mengerjakan tugas yang diberikan oleh guru tepat waktu.

\section{c) Peduli}

Arti kata peduli adalah mengindahkan, memperhatikan dan menghiraukan. Rasa kepedulian peserta didik harus mulai ditumbuhkan sejak berada di sekolah. Peserta didik juga dituntut untuk peduli terhaap lingkungan sekitarnya.

\section{d) Kerja Sama}

Kerja sama adalah suatu bentuk interaksi sosial antara orang-perorangan atau kelompok manusia untuk mencapai satu atau beberapa tujuan bersama. Kerja sama timbul karena orientasi orang-perorangan dengan kelompoknya (in group) dan kelompok lainnya (out group).

\section{e) Sederhana}

Hidup sederhana adalah hidup yang di sesuaikan dengan kebutuhan dan tidak berlebihan dalam menggunakan harta yang ada. Dengan gaya hidup sederhana, setiap peserta didik dibiasakan untuk tidak boros, hidup sesuai kemampuannya.

\section{Mata Pelajaran PKn}

a. Mandiri

\footnotetext{
${ }^{26}$ Mohammad Taufiq, Qur'an in World Ver 1.0.
} 
Mandiri dapat diartikan sebagai proses pendewasaan diri yang tidak bergantung pada orang lain untuk mengerjakan tugas dan tanggung jawabnya. Peserta didik dituntut untuk mengerjakan semua tanggung jawab dengan usahanya sendiri.

b. Ikhlas

Ikhlas ialah, menghendaki keridhaan Allah dalam suatu amal, membersihkannya dari segala individu maupun duniawi. Tidak ada yang melatar belakangi suatu amal, kecuali karena Allah dan demi hari akhirat.

c. Integritas

Integritas adalah mutu, sifat, atau keadaan yg menunjukkan kesatuan yg utuh sehingga memiliki potensi dan kemampuan yg memancarkan kejujuran. Nilai dan prinsip ini tentunya tidak lepas dari yang namanya kebenaran.

d. Kewarganegaraan

Kewarganegaraan adalah keanggotaan yang menunjukkan hubungan atau ikatan antara negara dengan warga negara. Pengertian Kewarganegaraan adalah segala jenis hubungan dengan suatu negara yang mengakibatkan adanya kewajiban negara itu untuk melindungi orang yang bersangkutan. Misalnya, mau berbagi tugas dalam pelaksanaan upacara di sekolah, taat pada aturan sekolah, menghormati para guru.

Tabel 4 di bawah ini menjelaskan indikator nilai-nilai pendidikan antikorupsi berdasarkan 9 nilai antikorupsi.

\begin{tabular}{|c|c|}
\hline Nilai-nilai & Indikator \\
\hline Jujur & $\begin{array}{ll}\text { - } & \text { Selalu berbicara dan berbuat sesuai dengan fakta } \\
\text { (konsisten). } \\
\text { - } \\
\text { - } & \text { Tidak melakukan perbuatan curang. } \\
\text { - } & \text { Tidak merbohong. } \\
& \text { Tidak mengai milik orang lain sebagai miliknya. }\end{array}$ \\
\hline Disiplin & $\begin{array}{l}\text { - Berkomitmen untuk selalu berperilaku konsisten dan } \\
\text { berpegang teguh pada aturan yang ada dalam semua } \\
\text { kegiatan. }\end{array}$ \\
\hline Peduli & $\begin{array}{ll}\text { - } & \text { Peduli terhadap bencana, kebakaran, banjir dan gempa } \\
\text { - } & \text { Peduli terhadap ancaman seperti narkoba. }\end{array}$ \\
\hline Kerja sama & $\begin{array}{l}\text { - } \quad \text { Senasib dan sepenanggungan. } \\
\text { - Rasa persaudaraan. }\end{array}$ \\
\hline Sederhana & $\begin{array}{l}\text { - Selalu berpenampilan apa adanya, tidak berlebihan, } \\
\text { tidak pamer, dan tidak ria. }\end{array}$ \\
\hline Mandiri & $\begin{array}{l}\text { - Selalu menuntaskan pekerjaan tanpa mengandalkan } \\
\text { bantuan dari orang lain. } \\
\text { - Tidak menyuruh-nyuruh atau menggunakan } \\
\text { kewenangannya untuk menyuruh orang lain terhadap } \\
\text { sesuatu yang mampu dikerjakan sendiri. }\end{array}$ \\
\hline Ikhlas/ketulusan & $\begin{array}{l}\text { - } \quad \text { Memberikan bantua kepada teman secara ikhlas } \\
\text { - } \quad \text { Apa yang dilakukan tidak mengharap upah. }\end{array}$ \\
\hline
\end{tabular}




\begin{tabular}{|c|c|}
\hline Kewarganegaraan & $\begin{array}{ll}\text { - } & \text { Membantu masyarakat. } \\
\text { - } & \text { Bertetangga yang baik. } \\
\text { - } & \text { Bekerja sama. }\end{array}$ \\
\hline Integritas & - $\quad$ Merasa menjadi satu kesatuan. \\
\hline
\end{tabular}

\section{G. Sikap Sosial Peserta Didik Pasca Belajar}

Untuk menilai sejauh mana nilai pendidikan anti korupsi dalam kurikulum pelajaran Akidah akhlak dan PKn dikelas IX MTs Al-Yusra Gorontalo dalam kehidupan sosial peserta didik, maka aspek penting yang diketahui adalah hubungan nilai-nilai pendidikan anti korupsi yang terdapat pada tiap-tiap mata pelajaran Akidah akhlak dan PKn dengan perilaku sosial peserta didik sehari-hari.

Penerapan nilai pendidikan antikorupsi mata pelajaran Akidah akhlak dan PKn pada konteks sosial peserta didik dapat dilihat dari hubungan-hubungan perilaku sosial peserta didik yang integratif dan korelatif dengan nilai pendidikan antikorupsi pada mata pelajaran-mata pelajaran yang banyak memuat nilai-nilai sosial, misal mata pelajaran PKn. Hampir keseluruhan dari nilai antikorupsi dalam mata pelajaran PKn memuat pesan-pesan moral-sosial yang dapat diamalkan oleh peserta didik dalam kehidupan sehari-harinya. Hal itu menunjukkan bahwa nilainilai antikorupsi yang diharapkan dapat diterapkan pada kehidupan sosial peserta didik dapat tercapai.

\section{H. Pengamalan Nilai-Nilai Islami dalam Kehidupan Peserta Didik}

Nilai-nilai pendidikan antikorupsi pada mata pelajaran Akidah akhlak dan PKn dalam kehidupan dirancang untuk mengantarkan siswa kepada peningkatan keimanan dan ketakwaan kepada Allah Swt, serta pembentukan akhlak yang mulia. Keimanan dan ketakwaan serta kemuliaan akhlak sebagaimana yang tertuang dalam tujuan dapat dicapai jika anak didik memiliki pengetahuan dan pemahaman yang utuh dan benar terhadap ajaran Islam, sehingga terinternalisasi dalam penghayatan dan kesadaran untuk melaksanakannya dengan benar. penelitian ini erat kaitannya dengan kehidupan mental atau rohani peserta didik sebagai implementasi dari nilai pendidikan antikorupsi yang diajarkan dalam kegiatan pembelajaran. Implikasi pendidikan antikorupsi dari aspek nilai islami dalam hal ini lebih umum karena ciri nilai-nilai islami pada diri setiap orang bersifat sama atau seragam dalam pelaksanaannya, yaitu lebih berorientasi pada rohani. 


\section{DAFTAR PUSTAKA}

Adithama, Toeti Prahas. 2012. 'Mengatasi Sumber Korupsi'. Media Indonesia, 19 Oktober 2012.

Atwell, Alison. 2013. Peningkatan Sekolah Efektif (Modul). Jakarta.

Danil Elwi, Konsep, Tindak Pidana, dan pemberantasannya, (Jakarta: Grafindo Persada, 2014)

Daryanto, 2011. Kepala Sekolah Sebagai Pemimpin Pembelajaran, (Yogyakarta: Gava Media).

Diat, L.P. 2011, Model Pendidikan Guru Masa Depan. Makalah. Administrasi Pendidikan FIP Universitas Yogyakarta.

Dhakidae, Danial. 2013. 'Kapital,korupsi, dan keadilan'. Prisma, Vol. 32, 2013.

E. Mulyasa. 2012. Manajemen Pendidikan Karakter. Jakarta: Bumi Aksara.

Gasak et, al (2011). Orang Kampung Melawan Korupsi, Jakarta : Kemitraan bagi Pembahruan Tata Pemerintahan.

Hazin kholif Nur, Penerbit “ Terbit Terang - Surabaya, 2014.

Harsono. 2011. Pendidikan untuk Semua. (Online) Surakarta: Universitas Muhamadiyah Surakarta.

Haryatmoko, 2011. Etika Puplik, untuk Integritas Pejabat Puplik dan Politisi. Jakarta: PT Gramedia Pustaka Utama.

Husen Achmad dan Supandi, (2013). Model Integrasi Pendidikan Antikorupsi Pada Mata Pelajaran Pendidikan Kewarganegaraan SMP/MTs Kelas VII. Jakarta: Direktorat Jendral Pendidikan Dasar, Kementerian Pendidikan dan Kebudayaan.

Idi, Abdullah dan Jamaludin. 2013. Filsafat Pendidikan: Filsafat Pendidikan Emile Durkhein.Jakarta; PT Raja Grafindo Persada

Idi, Abdullah dan Jamaludin. 2014. Materi Kuliah Sosiologi Pendidikan . S2/S2 Pascasarjana IAIN Raden Patah Palembang.

Jalaluddin dan Idi, A. 2012. Filsafat Pendidikan: Manusia, Filsafat dan Pendidikan, Yogyakarta: Ar-Ruzz Media. 
Khairon Herman. 2013. Etika Politik: Paradikma Politik Bersih,cerdas, Santun Berbasis Nilai Islam, Bandung; Nuansa Cendekia.

Kementerian Agama RI. 2013, Panduan Penyelenggaraan Pendidikan Antikorupsi di Madrasah, Jakarta: Direktorat Jendral Pendidikan Islam, Direktorat Madrasah, Kementerian Agama RI.

Kementerian Pendidikan Nasional Badan Peneliti Pengembangan Pusat Kurikulum, Bahan Pelatihan : Pengembangan Pendidikan Budaya dan Karakter Bangsa, Kendiknas, 2010.

Kementerian Agama RI. 2013, Panduan Penyelenggaraan Pendidikan Antikorupsi di Madrasah, Jakarta: Direktorat Jendral Pendidikan Islam, Direktorat Madrasah, Kementerian Agama RI.

Keputusan Direktur Jenderal Pendidikan Islam Nomor 1696 tahun 2013 tentang Panduan Penyelenggaraan Pendidikan Antikorupsi di Madrasah.

Mutiah, Siti, Korupsi Subur, Negara Hancur, Penerbit: Angkasa Bandung, 2011 :

Mulyana Rohmat, Mengartikulasikan Pendidikan Nilai, Penerbit Alfabeta, Bandung, 2011.

Mustari, Muhammad. 2014. Nilai Karakter: Refleksi untuk Pendidikan. Pengantar: Didik Suhardi. Jakarta: PT Raja Grafindo Persada.

Muhaimin. 2011. Manajemen Pendidikan, Aplikasi dalam Penyusunan Rencana Pengembangan Sekolah/ Madrasah. Jakarta: Kencana.

Muis, A. 2011. Paradigma Pendidikan Berwawasan Global dan Tantangannya di Masa Depan. Jurnal Medtek, Volume 3, Nomor 2, Oktober 2011.

Nurdin Muhamad, Pendidikan antikorupsi, Penerbit Ar-Ruzz Media, 2014.

Nurul Irfan. 2012. Korupsi dalam Hukum Pidana Islam, Jakarta Amzah.

Peraturan Presiden Republik Indonesia No 8 tahun 2012 tentang Kerangka Kualifikasi Nasional Indonesia. Jaringan dokumen dari Depatemen Pendidikan dan Kebudayaan.

Purwanto Nanang, Pengantar Pendidikan, Graha Ilmu, 2014. hlm, 23.

Sediyaningsih, S. 2012. Pendidikan Untuk Semua dan MDGs Dukungan Komunikasi Instruktusional dalam mewujudkan komitmen global di bidang pendidikan. 
Seputar Indonesia, Harian Umum, "Merancang Kado Istimewa Satu Abad Kemerdekaan”, Edisi 17 Agustus 2011, Jakarta, 2011.

Syauki Rif'at Nawawi. 2011. Kepribadian Qur'ani. Jakarta Amzah.

Suparno Paul dkk. 2012." Pendidikan Indonesia ; Harapan dan Kenyataan ." Kompas, 7 Mei 2012.

Sujarwo, 2012. Urgensi Nilai Moral dalam Pendidikan Karakter bagi Kehidupan Masyarakat.

Sediyaningsih, S. 2012. Pendidikan Untuk Semua dan MDGs Dukungan Komunikasi Instruktusional dalam mewujudkan komitmen global di bidang pendidikan.

Undang- Undang Nomor 20 Tahun 2003 Tentang Sistim Pendidikan Nasional .

Undang-Undang Nomor 31 Tahun 1999 Tentang Pemberantasan Tindak Pidana Korupsi

Undang -Undang Nomor 20 Tahun 2001 Tentang Perubahan atas UndangUndang Nomor 31 Tahun 1999 tentang pemberantasan Tindak Pidana Korupsi

Undang-Undang Nomor 30 Tahun 2002 Tentang Komisi Pemberantasan Tindak Pidana Korupsi.

Wijaya, David (2012). Pemasaran Jasa Pendidikan: Mengapa Sekolah Memerlukan Marketing? Jakarta : Salemba Empat.

Wijaya, David (2014). Lembar Kerja Siswa Pendidikan Antikorupsi SMP/MTs Kelas 7. Jakarta: Mitra Wacana Media.

Wijaya, David (2014). Lembar Kerja Siswa Pendidikan Antikorupsi SMP/MTs Kelas 8. Jakarta: Mitra Wacana Media.

Wijaya, David (2014). Lembar Kerja Siswa Pendidikan Antikorupsi SMP/MTs Kelas 9. Jakarta: Mitra Wacana Media.

Wijaya, David (2014). Manajemen Pendidikan Kontemporer, Jakarta: Media Bangsa.

Wijaya, David (2014). Manajemen Antikorupsi SMP/MTs kelas 7, Jakarta: Mitra Wacana Media.

Wijaya, David (2014). Manajemen Antikorupsi SMP/MTs kelas 8, Jakarta: Mitra Wacana Media. 
Wijaya, David (2014). Manajemen Antikorupsi SMP/MTs kelas 9, Jakarta: Mitra Wacana Media.

https://id.wikipedia.org/wiki/Strategi. diakses tanggal 16 September 2015.

http://tugasakhiramik.blogspot.co.id/2013/03/pengertian-implikasi.html.diakses tanggal 16 September 2015.

http://digilib.uinsby.ac.id/id/eprint/9569 diakses tgl 6 Oktober 2015.

http://www.koleksiskripsi.com/2012/04/52-nilai-nilai-antikorupsi-dalam.html, Diakses pada tanggal 17 Oktober 2012

http://lib.uin-malang.ac.id/files/thesis/fullchapter/04110025.pdf diakses tanggal 4 November 2015.

www.academia.edu/8555977/Kerangka_Dasar_Kurikulum_Tingkat_Satuan_Pend idikan diakses tanggal 4 November 2015.

http://afifahchaysl.blogspot.co.id/2013/04/aqidah-akhlak-mts.html. diakses tanggal 6 Nopember 2015.

http://hnd030485.blogspot.co.id/2013/02/ktsp-mts-nurul-islam-cirinten.html. diakses tanggal 6 Nopomber 2015.

http://phaninurcahyani.blogspot.co.id/2014/12/persamaan-dan-perbedaankurikulum-2006.html. di akses 9 Nopember 2015.

http://penelitiantindakankelas.blogspot.co.id/2013/07/pendekatan-scientificdalam-implementasi-kurikulum-2013.html. diakses tanggal 9 Nopember 2015.

http://zuhairistain.blogspot.co.id/2013/03/pengertian-perencanaan.html.diakses tanggal 10 Nopember 2015.

http://digilib.unila.ac.id/4718/11/BAB\%20II.pdf. Diakses pada tanggal 10 Nopember 2015.

https://akhmadsudrajat.wordpress.com/2008/03/21/penelitian-tindakan-kelas-partii/ diakses tanggal 26 Nopember 2015.

http://staff.uny.ac.id/sites/default/files/pengabdian/dra-endang-mulyatiningsih$\mathrm{mpd} / 8 \mathrm{cmetode}-$ penelitian-tindakan-kelas.pdf. diakses tanggal 28 Nopember 2015.

Repository.upi.edu/3642/ diakses tgl 16 Oktober 2013,Pk1 09.20 WITA. 